\title{
Internal Factor of Systemamtic Risk Model With Information Technology As Intervening Variables to Increasing Quality of Government Financial Reports In Indonesia: Actual Case From Riau Island Province
}

\author{
${ }^{1}$ Am. Riyadi, ${ }^{2}$ Muammar Khaddafi, ${ }^{3}$ Fuadi, ${ }^{4}$ Falahuddin, ${ }^{5}$ Rico Nur Ilham \\ ${ }^{1}$ Faculty of Economic and Business Universitas Batam \\ amri.ujs@gmail.com \\ 2,3,4,5 Faculty of Economic and Business Universitas Malikussaleh \\ khaddafi@unimal.ac.id, fuadi.msm@unimal.ac.id, falahuddin@unimal.ac.id, \\ riconurilham@unimal.ac.id \\ Coresponding Author: khaddafi@unimal.ac.id
}

\begin{abstract}
For the realization of the vision and mission of the Riau Islands Provincial Government, improving the competence of human resources in employees is an important aspect. Human Resources is the most important asset in the company. However, in practice it is not easy for organizations to make HR as a useful asset. Organizations need to implement a competency-based HR system to eliminate conflicts between organizations and employees, because in modern management philosophy, employees are human beings who have needs, expectations that need to be heard along with potential and competencies that can be developed to achieve organizational performance and performance. The purpose of this study was to determine the direct and indirect effect of the variable competence of human resources, job relevant information and financial planning on the quality of financial reports as well as through information technology. This study uses primary data derived from questionnaires and secondary data obtained from books and related literature. The data analysis technique uses the SEM version 3.0 tool. As for the results of this study, there is a direct influence of the Financial Planning variable on the Information Technology variable having a positive path coefficient. The direct influence of the Financial Planning variable on the Financial Statement Quality variable has a positive path coefficient. The direct influence of the Information Technology variable on the Financial Statement Quality variable has a path coefficient of positive. The direct influence of the Human Resources Competency variable on the Information Technology variable has a positive path coefficient. The direct influence of the Human Resources Competency variable on the Financial Statement Quality variable has a positive path coefficient. Variable direct effect Job Relevant Information on Information Technology variables has a path coefficient of positive. The direct influence of the Job Relevant Information variable on the Financial Statement Quality variable has a positive path coefficient.
\end{abstract}

Keywords: Human Resources Competence, Job Relevant Information, Financial Planning, Information Technology, Quality of Financial Reports

\section{PRELIMINARY}

Riau Archipelago Province is a province full of blessings from God Almighty. In addition to its very strategic geographical location because it is located at the entrance to the Malacca Strait from the east, it is also adjacent to the business and financial center in the Asia Pacific, namely Singapore. In addition, this province is also directly adjacent to Malaysia. With 
the motto Berpancang Amanah, Bersauh Marwah, Riau Islands Province is determined to build its region into one of the centers of national economic growth while maintaining the values of Malay Culture which is supported by a prosperous, intelligent, and noble society.

In empowering various existing potentials, Riau Islands Province strives to continue to create a conducive investment climate through the implementation of good governance and clean government by providing easy investment so that it can attract more domestic and foreign investors to invest their capital. Local government organizations are organizations engaged in public services. Therefore, the trust given by the community to government administrators must be balanced with good performance, so that services can be improved effectively. In this case, job relevant information helps provide better knowledge for organizations about alternative decisions and actions needed to achieve goals. Job Relevant Information (JRI) is internal organizational information that tends to be related to the tasks produced by employees. Such information can provide more precise environmental predictions and enable better policy choices, thereby improving performance. Job relevant information is one of the information that helps stakeholders to improve the choice of actions through well-informed efforts, both sourced from the company's external and internal environment. With the availability of job relevant information, it will encourage planning activities with the approach used to the task, and make employees will try to do more work compared to employees who do not have information.

Financial planning is an individual or organizational guide in managing finances for the future. In financial planning, in addition to the process of determining financial goals and financial priorities, it also considers the available resources, risk profile and organizational environment. Good financial planning will produce a clear financial plan and make it easier to achieve a financial goal. The purpose of financial planning is to save anything and make spending more effective, or use it for priority things. This means managing the amount of money coming in and going out properly. The function of financial planning is to manage finances for the future from as early as possible in achieving financial goals, carried out in a planned, regular and wise manner. Another function of financial planning is to allocate the organization's finances to the maximum. By making a list of financial planning, the organization's finances will be allocated to finance all interests that can have benefits within the organization's line. This process will go through a long step and end with a mutual agreement between the parties who have the authority.

The more technology develops, the more fields that exist and need to be developed. One of them is information technology. Information technology is a study of the design, implementation, development, support or management of computer-based information systems, especially in hardware (hardware) and software (computer software) applications. Information Technology (IT) is a general term for technology to assist humans in creating, transforming, storing, communicating, and disseminating information. Information technology is a technology that has a function in processing data, processing data, obtaining, compiling, storing, changing data in all kinds of ways to obtain useful or quality information. In addition, the function of information technology is to solve a problem, open creativity, increase effectiveness and efficiency in human activities. Information technology is not only important as a communication tool, but is an important tool that should be owned in organizations as a means to coordinate and archive important documents. Information technology is applied to 
manage information which is currently an important part due to the increasing complexity of management tasks, the influence of the international economy (globalization), and the need for a faster response time. Information technology in building an individual, organization, even a country has a big impact in making developments and progress.

In order to create good governance, local governments must make various efforts to increase transparency and accountability of regional financial managers. As an effort to increase transparency and accountability in regional financial management, the efforts made are to implement the development of government accounting policies in the form of government accounting standards which aim to provide basic guidelines in the preparation and presentation of local government financial reports to improve the quality of financial reports. Regional financial reports are prepared to provide relevant information regarding the financial position and all transactions carried out by local governments as a demand for public sector accountability related to the need for transparency and providing information to the public in the context of fulfilling public rights. The quality of financial reports is needed so that government financial reports can meet good quality, namely relevant, reliable, comparable, and easily understood. To be able to meet these qualitative characteristics, financial management in local governments cannot be separated from the role of employees who manage and carry out financial reporting in addition to utilizing advances in information technology, the work will be easier to have to have good capacity in managing local government finances by utilizing progress information Technology. Financial statements are said to be of high quality if the financial statements presented meet the requirements, namely properly accounted for, fully reported, independently audited.

\section{LITERATURE REVIEW AND HYPOTHESES}

\section{Human Resources Competence}

According to Lyle Spencer \& Signe Spencer (in Moeheriono, 2010: 3) human resource competence is the underlying characteristic of a person related to the effectiveness of individual performance in his work or basic characteristics of individuals who have a causal relationship or as a cause and effect with criteria that are used as references, effective or performing excellently or superiorly at work or in certain situations (A competency is an underlying characteristic of an individual that is causally related to criterian referenced effective and or superior).

\section{Job Relevant Information}

According to Kren (in Arlina Delas, 2015) job relevant information is information that facilitates task-related decision making. Job relevant information improves performance by providing a more accurate estimate of the environment so that the best course of effective action can be selected. According to Yusfaningrum (2005) in Rison (2017:4) job relevant information helps provide managers with better knowledge about alternative decisions and actions needed to achieve goals. With the availability of job relevant information, it will encourage planning activities with the approach used to the task, as well as helping individuals to make more efforts to do the task compared to individuals who do not have the information.

\section{Financial Planning}




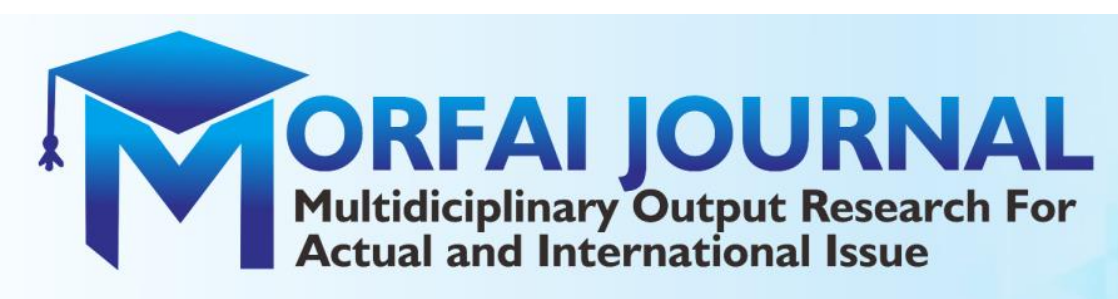

Financial planning is important in achieving a financial goal. According to Prita Hazari Ghozie (2014: 62), financial planning is a process in which a person or individuals strive to meet their financial goals through the development and implementation of a comprehensive financial plan and good financial planning will result in a clear and concise financial plan. make financial planning easier

\section{Information Technology}

According to Lantip and Rianto (2011:4) information technology is defined as science in the field of computer-based information and its development is very rapid. Hamzah B. Uno and Nina Lamatenggo (2011:57) also stated that information technology is a technology used to process data. Processing includes processing, obtaining, compiling, storing, manipulating data in various ways to produce quality information, namely information that is relevant, accurate, and timely.

\section{Financial Report Quality}

Afiyah (2010:164) defines financial statements as the result of the accounting process in accordance with the accounting cycle previously carried out by the OPD, namely the document identification stage, journalizing stage, and posting stage to the ledger of each account. According to Bastian (2010: 96), financial statements are written reports that provide quantitative information and represent the financial position of transactions carried out by an entity. According to Defitri (2016) the quality of local government financial reports is the ability of the information presented in financial statements to be understood, and meet the needs of users in decision making, free from misleading understanding, material errors and reliable so that the financial statements can be compared with other periods. previously.

\section{Hypothesis}

H1: Competence of human resources has a direct effect on information technology for employees of the Riau Islands Provincial Government.

$\mathrm{H} 2$ : Job relevant information has a direct effect on information technology for employees of the Riau Islands Provincial Government.

H3: Financial planning has a direct effect on information technology for employees of the Riau Islands Provincial Government.

H4: Information technology has a direct effect on the quality of the financial statements of employees of the Riau Islands Provincial Government.

H5: The competence of human resources has a direct effect on the quality of the financial statements of the employees of the Riau Islands Provincial Government.

H6: Job relevant information has a direct effect on the quality of the financial statements of employees of the Riau Islands Provincial Government.

H7: Financial planning has a direct effect on the quality of the financial statements of employees of the Riau Islands Provincial Government. 


\section{RESEARCH METHODS}

\section{Location and Time}

Research conducted by researchers is to determine the object to be studied in accordance with the object to be taken by the researcher. This research was conducted on employees within the Riau Islands Provincial Government with certain positions, for a period of three months from November 2020 to January 2021. The research begins with literature searches, submitting and examining research proposals, collecting and processing data, completing thesis reports up to thesis exam

\section{Research Methods}

The research method is one of the ways taken to achieve a goal, while the purpose of the research is to reveal, describe, conclude the results of problem solving through certain methods in accordance with the research procedures. The research method will direct the research to the research objectives. This research method uses a causal model survey method using path analysis techniques. Based on the reasons this study aims to confirm the theoretical model with empirical data. This study attempts to test the hypothesis used where this study will take a sample from a population and use a questionnaire as the main data collector.

\section{Population}

According to Nazir (2006), the population is a collection of individuals with predetermined qualities and characteristics. And according to Sugiyono (2008) states that the population is a generalization area consisting of objects/subjects that have certain quantities and characteristics determined by researchers to be studied and then drawn conclusions. From this understanding, it can be interpreted that the population in this study is civil servants who hold the position of Head of Finance in each OPD (Regional Apparatus Organization) within the Riau Islands Provincial Government, totaling 41 people with certain tasks. Arikunto (in Riduwan, 2012: 210) suggests that if the subject is less than 100, it is better to take all of them, so that the research is a population study. Due to population limitations, all members of the population were used as research samples so that this study used a saturated sample whose collection was carried out through the Census Technique using proportional random sampling.

\section{Sample}

According to Rumengan, et al (2015: 51) what is meant by the sample is part of the population with characteristics that are considered representative of the research population. The sample is part of the population (Umar, 2010; Sekaran, 2011). The sample consists of a number of members selected from the population or subgroups of the population. The sample of this research was taken by descriptive research method with a quantitative approach which aims to show the relationship between variables and the research technique in the form of a survey and the research instrument in the form of a questionnaire. With this method is expected to accurately describe the relationship of independent variables and dependent variables in the study and by using statistics that measure these variables so that it can explain the situation correctly. Descriptive method in the investigation through the activities of telling, describing, analyzing and clarifying the investigation with survey techniques, questionnaires, and observation. Because the sample is 
used to represent the population being studied, the sample tends to be used for research that seeks to conclude generalizations from the findings.

\section{Data Collection Technique}

The data collection technique used variable measurement using a questionnaire instrument. Each employee respondent was given five questionnaire instruments to be a source of measurement of the variables studied. Data were collected using the questionnaire method, namely by providing a list of questions or questionnaires to the respondents. The reason for using this method is that the research subjects are the people who know best about themselves, and the statements given by the subjects are true and reliable. Answers to the list of questions that must be filled out by respondents are made using a Likert scale, which ranges from 1 to 5 , where a value of 1 is a statement of strongly disagree and a value of 5 is a statement of strongly agree.

\section{RESULTS AND DISCUSSION Validity and Reliability Test}

Based on the table above, it can be seen that the value of outer loading for variables $\mathrm{X} 1$, $\mathrm{X} 2, \mathrm{X} 3, \mathrm{X} 4, \mathrm{Y}$ where the value of all question items on the 5 variables tested is greater than 0.4 then all indicators on 5 variables are declared valid.

Based on the table above, the correlation between X1 and X2 is 0.428 . The correlation between $X 1$ and $X 3$ is 0.475 . The correlation between $X 1$ and $X 4$ is 0.399 . The correlation between $\mathrm{X} 1$ and $\mathrm{Y}$ is 0.438 . All variables have a correlation value $<0.900$, thus the correlation value of all variables is declared valid.

Based on the table above, the correlation between $\mathrm{X} 3$ and $\mathrm{X} 2$ is 0.699 . The correlation between $\mathrm{X} 4$ and $\mathrm{X} 2$ is 0.688 . The correlation between $\mathrm{Y}$ and $\mathrm{X} 2$ is 0.645 . All variables have a correlation value $<0.900$, thus the correlation value of all variables is declared valid.

It can also be seen that the table above also shows that the correlation between $\mathrm{X} 4$ and $\mathrm{X} 3$ is 0.641 , the correlation between $\mathrm{Y}$ and $\mathrm{X} 3$ is 0.614 . All variables have a correlation value of $<0.900$, thus the correlation value of all variables is declared valid.

Finally, from the table above, it is also found that the correlation between $\mathrm{Y}$ and $\mathrm{X} 4$ is 0.575 . All variables have a correlation value of $<0.900$, so the correlation value of all variables is declared valid.

Based on the internal consistency analysis data in the table, the results show that the X1 variable has a composite reliability value of $0.881>0.600$ then the $\mathrm{X} 1$ variable is reliable, then the X2 variable has a composite reliability value of $0.905>0.600$ then the $\mathrm{X} 2$ variable is reliable, the $\mathrm{X} 3$ variable has a composite reliability value of $0.887>0.600$ then the $\mathrm{X} 3$ variable is reliable, the $\mathrm{X} 4$ variable has a composite reliability value of $0.922>0.600$ then the $\mathrm{X} 4$ variable is reliable, the $\mathrm{Y}$ variable has a composite reliability value of $0.882>0.600$ then the $\mathrm{Y}$ variable is reliable. 


\section{Morfal journal \\ Multidiciplinary Output Research For \\ Actual and International Issue}

\section{Hypothesis test}

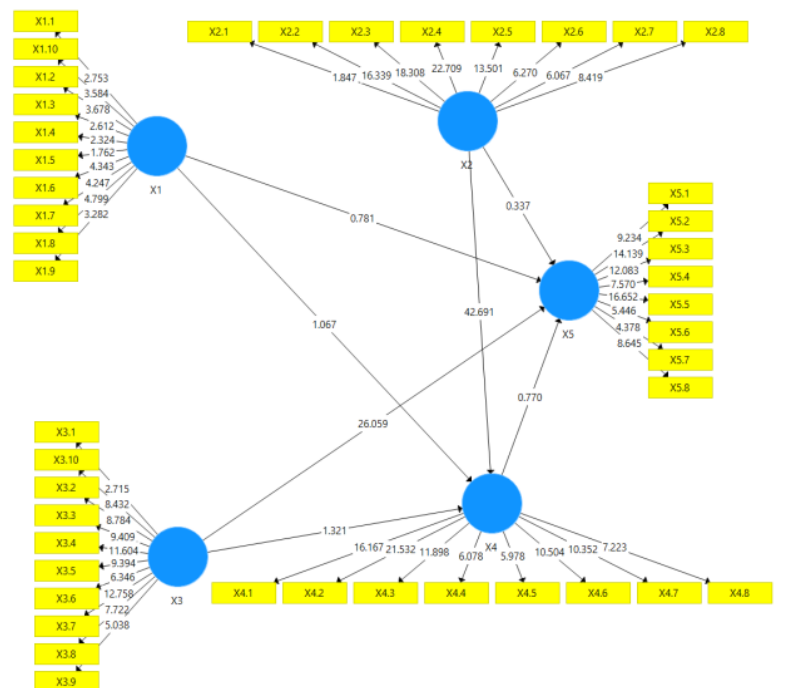

Testing the direct influence hypothesis aims to prove the hypotheses of the influence of one variable on other variables directly (without intermediaries). If the path coefficient value is positive, it indicates that an increase in the value of one variable is followed by an increase in the value of other variables. If the path coefficient value is negative, it indicates that an increase in the value of a variable is followed by a decrease in the value of other variables.

If the probability value $(\mathrm{P}-\mathrm{Value})<$ Alpha $(0.05)$ then Ho is rejected (the influence of a variable with other variables is significant). If the probability value (P-Value) $>$ Alpha (0.05) then Ho is rejected (the influence of a variable with other variables is not significant)

\section{Direct Effect Hypothesis}

\begin{tabular}{|l|l|l|l|l|l|}
\hline Variable & $\begin{array}{l}\text { Original } \\
\text { Sample }\end{array}$ & $\begin{array}{l}\text { Sample } \\
\text { Average }\end{array}$ & $\begin{array}{l}\text { Standard } \\
\text { Deviation }\end{array}$ & $\begin{array}{l}\text { T } \\
\text { Statistics }\end{array}$ & $\begin{array}{l}\mathbf{P} \\
\text { Values }\end{array}$ \\
\hline X1 -> X4 & 0.039 & 0.034 & 0.037 & 1.067 & $\mathbf{0 . 1 5 7}$ \\
\hline $\mathbf{X 1}$-> Y & -0.027 & -0.033 & 0.035 & 0.781 & $\mathbf{0 . 4 8 6}$ \\
\hline $\mathbf{X} 2$-> X4 & 0.994 & 0.994 & 0.023 & 42,691 & $\mathbf{0 . 0 0 0}$ \\
\hline $\mathbf{X} 2$-> Y & 0.054 & 0.064 & 0.161 & 0.337 & $\mathbf{0 . 7 3 2}$ \\
\hline $\mathbf{X 3 ~}$-> X4 & -0.043 & -0.045 & 0.033 & 1.321 & $\mathbf{0 . 1 2 9}$ \\
\hline $\mathbf{X 3 ~}$-> Y & 1.023 & 1.030 & 0.039 & 26.059 & $\mathbf{0 . 0 0 0}$ \\
\hline $\mathbf{X 4}$-> Y & -0.104 & -0.121 & 0.135 & 0.770 & $\mathbf{0 . 4 7 5}$ \\
\hline
\end{tabular}

The direct effect of the $\mathrm{X} 3$ variable on the $\mathrm{X} 4$ variable has a path coefficient of 1.321 (positive), then an increase in the value of the $\mathrm{X} 3$ variable will be followed by an increase in the $\mathrm{X} 4$ variable. The effect of the $\mathrm{X} 3$ variable on $\mathrm{X} 4$ has a P-Values value of $0.129>0.05$, so it can be stated that the effect of $\mathrm{X} 3$ on $\mathrm{X} 4$ is not significant.

The direct effect of variable $X 3$ on variable $Y$ has a path coefficient of 26,059 (positive), then an increase in the value of variable $\mathrm{X} 3$ will be followed by an increase in variable $\mathrm{Y}$. The effect of variable $\mathrm{X} 3$ on $\mathrm{Y}$ has a $\mathrm{P}-$ Values value of $0.000<0.05$, so it can be stated that the effect between $\mathrm{X} 3$ against $\mathrm{Y}$ is significant. 


\section{ORFAI JOURNAL \\ Multidiciplinary Output Research For \\ Actual and International Issue}

The direct effect of the $\mathrm{X} 4$ variable on the $\mathrm{Y}$ variable has a path coefficient of 0.770 (positive), then the increase in the value of the $\mathrm{X} 4$ variable will be followed by an increase in the $\mathrm{Y}$ variable. $\mathrm{X} 4$ against $\mathrm{Y}$ is not significant.

The direct effect of the X1 variable on the X4 variable has a path coefficient of 1,067 (positive), then the increase in the value of the $\mathrm{X} 1$ variable will be followed by an increase in the $\mathrm{X} 4$ variable. The effect of the $\mathrm{X} 1$ variable on $\mathrm{X} 4$ has a P-Values value of $0.157>0.05$, so it can be stated that the effect of $\mathrm{X} 1$ on $\mathrm{X} 4$ is not significant.

The direct effect of variable $\mathrm{X} 1$ on variable $\mathrm{Y}$ has a path coefficient of 0.781 (positive), then an increase in the value of variable $\mathrm{X} 1$ will be followed by an increase in variable $\mathrm{Y}$. The effect of variable $\mathrm{X} 1$ on $\mathrm{Y}$ has a $\mathrm{P}-\mathrm{V}$ alues value of $0.486<0.05$, so it can be stated that the effect between $\mathrm{X} 1$ to $\mathrm{Y}$ is not significant.

The direct effect of the X2 variable on the X4 variable has a path coefficient of 42,691 (positive), then the increase in the value of the $\mathrm{X} 2$ variable will be followed by an increase in the $\mathrm{X} 4$ variable. The effect of the $\mathrm{X} 2$ variable on $\mathrm{X} 4$ has a $\mathrm{P}$-Values value of $0.000<0.05$, so it can be stated that the effect of $\mathrm{X} 2$ on $\mathrm{X} 4$ is significant.

The direct effect of the $\mathrm{X} 2$ variable on the $\mathrm{Y}$ variable has a path coefficient of 0.337 (positive), then the increase in the value of the $\mathrm{X} 2$ variable will be followed by an increase in the $\mathrm{X} 4$ variable. The effect of the $\mathrm{X} 2$ variable on $\mathrm{Y}$ has a $\mathrm{P}$-Values value of $0.732>0.05$, so it can be stated that the effect of $\mathrm{X} 2$ on $\mathrm{Y}$ is not significant.

The indirect effect hypothesis testing aims to prove the hypotheses of the influence of one variable on other variables indirectly (through intermediaries). If the coefficient of indirect effect $>$ direct effect coefficient, then the intervening variable is mediating the relationship between one variable and another. On the other hand, if the coefficient of indirect effect is < the coefficient of direct influence, then the intervening variable is not mediating the relationship between one variable and another.

Indirect Effect Hypothesis Table

\begin{tabular}{|l|l|l|l|l|l|}
\hline Variable & $\begin{array}{l}\text { Original } \\
\text { Sample }\end{array}$ & $\begin{array}{l}\text { Sample } \\
\text { Average }\end{array}$ & $\begin{array}{l}\text { Standard } \\
\text { Deviation }\end{array}$ & $\begin{array}{l}\text { T } \\
\text { Statistics }\end{array}$ & $\begin{array}{l}\text { P } \\
\text { Values }\end{array}$ \\
\hline X1 $\boldsymbol{~ > ~ X 4 ~}$-> Y & -0.004 & -0.003 & 0.010 & 0.396 & $\mathbf{0 . 6 9 4}$ \\
\hline X2 $->$ X4 -> Y & -0.103 & -0.120 & 0.136 & 0.764 & $\mathbf{0 . 4 4 9}$ \\
\hline X3 $>$ X4 -> Y & 0.004 & 0.006 & 0.010 & 0.464 & $\mathbf{0 . 6 4 5}$ \\
\hline
\end{tabular}

Based on the table above, the coefficient value of the indirect effect of $\mathrm{X} 1$ on $\mathrm{Y}$ is 0.781 $>0.396$ (direct effect of $\mathrm{X} 1$ on $\mathrm{Y}$ ) thus it can be stated that X4 mediates the effect of X1 on Y.

Furthermore, the coefficient value of the indirect effect of the $\mathrm{X} 2$ variable on $\mathrm{Y}$ is 0.337 $<0.764$ (direct effect of $\mathrm{X} 2$ on $\mathrm{Y}$ ) thus it can be stated that X4 does not mediate the effect of $\mathrm{X} 2$ on $\mathrm{Y}$.

Then, the value of the coefficient of the indirect effect of the variable $\mathrm{X} 3$ on $\mathrm{Y}$ is 26,059 $>0.464$ (direct effect of $\mathrm{X} 1$ on $\mathrm{Y}$ ) thus it can be stated that $\mathrm{X} 4$ mediates the effect of $\mathrm{X} 3$ on $\mathrm{Y}$. 


\section{Coefficient of Determination}

\begin{tabular}{|l|l|l|}
\hline Variable & R Square & Adjusted R Square \\
\hline X4 & 0.966 & 0.963 \\
\hline Y & 0.972 & 0.969 \\
\hline
\end{tabular}

The table above shows that the effect of X1, X2 and X3 on X4 (e1) is 0.966 , meaning that the magnitude of the effect of $\mathrm{X} 1, \mathrm{X} 2$ and $\mathrm{X} 3$ on $\mathrm{X} 4$ is $96.60 \%$. Then, the effect of $\mathrm{X} 1, \mathrm{X} 3$ and $\mathrm{X} 4$ on $\mathrm{Y}$ is 0.972 , meaning that the magnitude of the effect of $\mathrm{X} 1, \mathrm{X} 3$ and $\mathrm{X} 4$ on $\mathrm{Y}$ is $97.20 \%$.

\section{The Effect of Financial Planning on Information Technology}

Financial planning is a process in which a person or individuals strive to meet their financial goals through the development and implementation of a comprehensive financial plan and good financial planning will produce a clear financial plan and facilitate financial planning. Cannot significantly affect IT which is the result of human engineering on the process of delivering information from sender to recipient so that it is faster, wider in distribution, longer in storage

\section{The Effect of Financial Planning on the Quality of Financial Reports}

Financial planning is a process in which a person or individuals strive to meet their financial goals through the development and implementation of a comprehensive financial plan and good financial planning will produce a clear financial plan and facilitate financial planning. Able to significantly influence the quality of local government financial reports, namely the ability of the information presented in the financial statements to be understood, and meet the needs of users in making decisions, free from misleading understanding, material errors and reliable so that the financial statements can be compared with previous periods.

\section{The Effect of Information Technology on the Quality of Financial Reports}

IT is the result of human engineering on the process of delivering information from the sender to the recipient so that it is faster, wider in distribution, longer in storage, it turns out that it cannot significantly affect the quality of local government financial reports, namely the ability of the information presented in financial statements to be understood, and to meet the needs of its users. in making decisions, free from misleading understanding, material errors and reliable so that the financial statements can be compared with previous periods.

\section{The Influence of Human Resource Competence on Information Technology}

Human resource competencies are characteristics that underlie a person related to the effectiveness of individual performance in his work or basic characteristics of individuals that have a causal relationship or as a cause-and-effect relationship with criteria that are used as references, effective or excellent or superior performance in the workplace or in certain situations unable to influence significantly information technology is all forms of technology that is applied to process and transmit information in the form of electronic, microcomputer, mainframe computer. 
The Influence of Human Resource Competence on the Quality of Financial Reports

Human resource competencies are characteristics that underlie a person related to the effectiveness of individual performance in his work or basic characteristics of individuals who have a causal relationship or as a cause and effect with criteria that are used as references, are effective or perform excellent or superior at work or in certain situations are unable to significantly affect the quality of local government financial reports, namely the ability of the information presented in the financial statements to be understood, and to meet the needs of users in making decisions, free from misleading notions, material errors and reliable so that the financial statements can be compared with previous periods.

\section{The Influence of Job Relevant Information on Information Technology}

Job relevant information is information that facilitates task-related decision making. Job relevant information improves performance by providing a more accurate estimate of the environment so that the best course of effective action can be selected. Being able to significantly influence information technology is any form of technology that is applied to process and transmit information in the form of electronics, micro computers, mainframe computers.

\section{The Influence of Job Relevant Information on the Quality of Financial Reports}

Job relevant information is information that facilitates task-related decision making. Job relevant information improves performance by providing more accurate estimates of the environment so that the best effective courses of action can be selected. Not able to significantly affect the quality of local government financial reports, namely the ability of the information presented in financial reports to be understood, and to meet the needs of users in making decisions, free of charge. from misleading notions, material errors and can be relied upon so that the financial statements can be compared with previous periods

\section{CONCLUSION, LIMITATIONS AND SUGGESTIONS} Research Limitations

This study has several limitations that may interfere with the results of the study. These limitations include: The data of this study were generated from instruments that were built from theory and then developed into questions based on respondents' answers in the form of a Likert scale. This raises many problems including the psychological factor of the respondent in answering the questionnaire so that it contains a very high subjective element. In addition, this research is based on a survey method through questionnaires, the researchers did not conduct interviews, so the conclusions raised are only based on the data collected through tabulations which are managed using path analysis data analysis tools so that between researchers and respondents do not interact directly or do not create a relationship. as well as in-depth interactions in interpreting research for future theory development.

\section{Conclusion}

The findings of data analysis in the discussion and hypothesis testing, it can be concluded as follows:

The direct influence of the Financial Planning variable on the Information Technology variable has a positive path coefficient, the direct effect of the $\mathrm{X} 3$ variable on the $\mathrm{X} 4$ variable 
has a path coefficient of 1.321 (positive), then the increase in the value of the $\mathrm{X} 3$ variable will be followed by an increase in the X4 variable. The effect of the X3 variable on X4 has a PValues value of $0.129>0.05$, so it can be stated that the effect of X3 on X4 is not significant.

The direct effect of the Financial Planning variable on the Financial Statement Quality variable has a positive path coefficient, the direct effect of the $\mathrm{X} 3$ variable on the $\mathrm{Y}$ variable has a path coefficient of 26,059 (positive), then the increase in the value of the X3 variable will be followed by an increase in the $\mathrm{Y}$ variable. The influence of the $\mathrm{X} 3$ variable on $\mathrm{Y}$ has a $\mathrm{P}$ value -Values of $0.000<0.05$, so it can be stated that the effect of $\mathrm{X} 3$ on $\mathrm{Y}$ is significant

The direct effect of the Information Technology variable on the Financial Statement Quality variable has a path coefficient of positive, the direct effect of the $\mathrm{X} 4$ variable on the $\mathrm{Y}$ variable has a path coefficient of 0.770 (positive), then an increase in the value of the $\mathrm{X} 4$ variable will be followed by an increase in the $\mathrm{Y}$ variable. The influence of the $\mathrm{X} 4$ variable on $\mathrm{Y}$ has a value P-Values are $0.475>0.05$, so it can be stated that the effect of X4 on $\mathrm{Y}$ is not significant.

The direct influence of the Human Resources Competency variable on the Information Technology variable has a positive path coefficient, the direct effect of the X1 variable on the X4 variable has a path coefficient of 1,067 (positive), then the increase in the value of the X1 variable will be followed by an increase in the $\mathrm{X} 4$ variable. The effect of the $\mathrm{X} 1$ variable on $\mathrm{X} 4$ has a P-Values value of $0.157>0.05$, so it can be stated that the effect of X1 on X4 is not significant.

The direct influence of the Human Resource Competence variable on the Financial Statement Quality variable has a positive path coefficient, the direct effect of the X1 variable on the $\mathrm{Y}$ variable has a path coefficient of 0.781 (positive), then the increase in the value of the $\mathrm{X} 1$ variable will be followed by an increase in the $\mathrm{Y}$ variable. The influence of the $\mathrm{X} 1$ variable on $\mathrm{Y}$ has $\mathrm{P}-$ Values value is $0.486>0.05$, so it can be stated that the effect of $\mathrm{X} 1$ on $\mathrm{Y}$ is not significant.

The direct effect of the Job Relevant Information variable on the Information Technology variable has a path coefficient of positive, the direct effect of the X2 variable on the X4 variable has a path coefficient of 42,691 (positive), then an increase in the value of the $\mathrm{X} 2$ variable will be followed by an increase in the $\mathrm{X} 4$ variable. The effect of the $\mathrm{X} 2$ variable on $\mathrm{X} 4$ has a P-Values value of $0.000<0.05$, so it can be stated that the effect of $\mathrm{X} 2$ on $\mathrm{X} 4$ is significant.

The direct effect of the Job Relevant Information variable on the Financial Report Quality variable has a positive path coefficient, the direct effect of the X2 variable on the $\mathrm{Y}$ variable has a path coefficient of 0.337 (positive), then an increase in the value of the X2 variable will be followed by an increase in the $\mathrm{X} 4$ variable. The effect of the $\mathrm{X} 2$ variable on $\mathrm{Y}$ has a P-Values value of $0.732>0.05$, so it can be stated that the effect of $\mathrm{X} 2$ on $\mathrm{Y}$ is not significant.

\section{Suggestion}

1. Resource development through education and training needs to be improved and carefully re-planned so that the implementation of human resource development can affect employee performance. 
2. For the heads of the finance department, it is expected to further improve coordination with the leaders of the finance department in other fields, so that the information related to the task is able to assist the finance department in making decisions when preparing the budget.

3. The need for good financial planning, for that the need for a role in every power user of the budget in coordinating the achievement of the organization.

4. In the Utilization of Information Technology, it is necessary to improve computer networks related to access to financial systems so that they do not often experience errors. The addition of servers and bandwidth can be an alternative solution to improve the quality of the computer network used for the Financial Accounting System. With the increase in the improvement of the Financial Accounting System and the increase in the Utilization of Information Technology, it is expected to improve the Quality of Financial Reports.

5. To improve the financial accounting system, recording activities must be more thorough in recording every transaction, every transaction must use transaction evidence in order to avoid inaccurate recording, and it is necessary to supervise and control the recording and reporting of evidence of transactions using funds carried out.

\section{REFERENCES}

AA Anwar Prabu Mangkunegara (2012). Human Resource Management. Bandung: PT. Rosdakarya Youth.

Abdul Kadir and Terra Ch. Triwahyuni. 2013. Introduction to Information Technology Revised Edition. Yogyakarta: Andi

Alie, Y., \& Rodiyah. (2013). Effect of Effective Cough on Sputum Expenditure in Tuberculosis Patients at the Peterongan Health Center, Jombang Regency. Journal of Metabolism, 2(3), 15-21. https://doi.org/10.1111/jce.12992.This

Arlina Delas Umayah. 2015. The Influence of Reward System, Job Relevant Information (JRO), and Manager's Value Orientation Toward Innovation (VOI Manager) on Employee Performance Through Job Satisfaction as an Intervening Variable (Case Study at PT WIKA Head Office Jakarta Building)

Asmani, Jamal Ma'mur. 2011. Guidebook for Internalization of Character Education in Schools. Yogyakarta: Diva Press.

Basri, F and Munandar, H. (2010), â€œBasics - Fundamentals of International Economics: Introduction \& Application of Quantitative Methodsâ€ , First Edition, Kencana, Jakarta.

Darmawan, Deni. 2012. Information and Communication Technology Education. Bandung: PT Pemuda Rosdakarya.

Ghozie, PH 2016. Make it happen! Smart book financial plans to make dreams come true. Publisher PT Gramedia Pustaka Utama, Jakarta.

Ghozie, Prita Hapsari. 2014. Make It Happen (Financial Plan Smart Book to Realize Dreams). Jakarta: PT. Gramedia Pustaka Utama.

Hamzah B. Uno and Nina Lamatenggo, Learning Information and Communication Technology, Jakarta: PT Bumi Aksara, 2011, cet, 2 
Ihsanti, Emilda. 2014. The Influence of Human Resource Competence and the Implementation of Regional Financial Accounting Information Systems on the Quality of Regional Financial Reports.

Ilham, Rico Nur et all. (2019). Investigation of the Bitcoin Effects on the Country Revenues via Virtual Tax Transactions for Purchasing Management. International Journal of Suplly Management.Volume 8 No.6 December 2019.

Ilham, Rico Nur et all. (2019). Comparative of the Supply Chain and Block Chains to Increase the Country Revenues via Virtual Tax Transactions and Replacing Future of Money. International Journal of Suplly Management.Volume 8 No.5 August 2019.

M. Khaddafi, R. A. Aryani, and M. Heikal, "The Effect Of Financial Knowledge And Personal Net Income On The Financial Behavior Of Malikussaleh University Employees With Locus Of Control As Moderating Variables”, IJEBAS, vol. 1, no. 1, pp. 1-13, Oct. 2021. Indrajit, Richardus Eko. 2011. The Role of Information Technology and the Internet. Yogyakarta: Andi Offest.

Karvof, Anatoli A. 2010. Rich with CEPIL; Smart Ways to Achieve Financial Wealth and Blessing. Elex Media Komputindo. Jakarta.

Megawati, Luh Kadek Sri.Dkk. 2015. The Influence of the Implementation of the Local Government Financial Accounting System, Human Resource Competence and Regional Financial Management on the Quality of Local Government Financial Reports (Empirical Study of Three Buleleng District Offices). E-Journal of S1 Accounting, Ganesha University of Education. Vol 3 No. 1

Moeheriono, (2014). Competency-based Performance Measurement. Bogor : Ghalia Indonesia Publisher.

Mulyadi. 2014. Accounting System.Yogyakarta: Salemba Empat.

Nordiawan, Deddi and Ayuningtyas Hertianti. 2010. Public Sector Accounting. Second Edition. Jakarta:Four Salemba

Prasojo Diat Lantip, Riyanto, Education Information Technology Yogyakarta: Gava Media, 2011.

R. Nur Ilham, M. . Sumatrani Saragih, and A. . Saifannur, "Effect Of Working Capital Management And Leverage On Company Value With Profitability As Moderating Variables: Empirical Study On Manufacturing Companies Listed On The Indonesia Stock Exchange”, IJEBAS, vol. 1, no. 1, pp. 41-53, Oct. 2021.

Rumengan Jemmy/Satriawan Bambang/Juliandi, Azuar/Irfan, (2011), Path Analysis with SPSS, Diktat lectures and training. BATAM: UNIBA

Rumengan Jemmy, Suhardis Adnan, Rumengan Tommy 2020. Health Research Methodology. Sefa Bumi Persada ISBN-978-623-7648-49-9.

Rumengan Jemmy, Juliandi Azuar, Gaddafi Muammar, Rumengan Eleonora Angelina 2019. Research Methods. Sefa Bumi Persada ISBN-978-602-0768-85-4.

Rumengan Jemmy, Gaddafi Muammar, Syarif Arman, Yanti Sri 2020. Research Methodology. Sefa Bumi Persada. ISBN-978-623-7648-57-4.

Rusman, et al (2011) Information and Communication Technology-Based Learning: Developing Teacher Professionalism. Jakarta: Rajawali Press. PT. King Grafindo Persada 
Sadalia, I, Syahyunan dan Butar-Butar, N A. 2017. "Financial Behavior and Performance on Small and Medium Enterprises in Coastal Area of Medan City", IOP Conf. Series Materials Science and Engineering 180 (2017) 012257. Medan.

Sina, Peter Garlans. (2012). Economic Literacy Analysis. Journal of Ecnomia, volume 8, No.2, October 2012

Sobaya, S., Hidayanto, MF, \& Safitri, J. (2016). The Effect of Financial Literacy and Social Environment on Employee Financial Planning at the Islamic University of Indonesia Yogyakarta. MADANIA, 115-128.

Spencer, Lyle M. and Signe M. Spencer. (2010). Competence at work: Models for Superior Performance. Canada: John Wiley \& Sons.

Subiaktono. (2013). The Influence of Personality Traits on Family Financial Planning. Journal of Management Dynamics, 150-163.

Sudarmanto. 2014. Human Resources Performance and Competency Development. Second printing. Yogyakarta : Student Library

Sutrisno, 2012. Human Resource Management. Jakarta : Kencana Wibowo. 2013. Behavior in Organizations.. Jakarta: PT. King Grafindo Persada Hero. (2015). Indonesian Human Resource Management. Jakarta: PT Raja Grafindo Persada. 